\title{
Hit Harder, Recover Slower? Unequal Employment Effects of the COVID-19 Shock
}

\author{
Sang Yoon (Tim) Lee, Minsung Park, and Yongseok Shin
}

\begin{abstract}
The destructive economic impact of the COVID-19 pandemic was distributed unequally across the population. A worker's gender, race and ethnicity, age, education, industry, and occupation all mattered. We analyze the initial negative effect and its lingering effect through the recovery phase, across demographic and socioeconomic groups. The initial negative impact on employment was larger for women, minorities, the less educated, and the young whether or not we account for the industries and occupations they worked in. By February 2021, however, the differential effects across groups had gotten much smaller overall and had entirely vanished once the different industries and occupations they work in are taken into account. In particular, the differential effects between men and women vanished with or without the industry and occupation compositions taken into account, indicating that women's progress in the labor market over the past decades has not been wiped out by the pandemic. Across race and ethnicity, Hispanics and Asians were the worse hit but made up most of the lost ground, while the initial impact on Blacks was smaller but their recovery was slower. (JEL J21, J15, J16)
\end{abstract}

Federal Reserve Bank of St. Louis Review, Forthcoming 2021.

A s late as February 2020, the U.S. labor market was booming. The unemployment rate stood at 3.5 percent, a record low since December 1969. COVID-19 struck out of the blue with unprecedented speed and ferocity. U.S. unemployment spiked to 14.7 percent in April 2020, although by October 2020 it had fallen to below 7 percent and has remained below that level to date. Although COVID-19's impact on the labor market has been multifaceted, it broadly materialized through two channels. The first was through the voluntary reduction in consumer and business activities, especially contact-intensive ones, out of fear of infection. The other was through government containment policies, such as various social distancing measures and lockdowns of large swaths of the economy, especially targeted toward jobs categorized as "nonessential."

Sang Yoon (Tim) Lee is a reader at Queen Mary University of London. Minsung Park is a Ph.D. candidate at Washington University in St. Louis. Yongseok Shin is a professor of economics at Washington University in St. Louis and a research fellow at the Federal Reserve Bank of St. Louis. We thank Juan Sanchez, Co-Editor-in Chief, and an anonymous referee for several helpful suggestions. We also benefited from our conversations with Alyssa Fowers of the Washington Post. Sang Yoon (Tim) Lee gratefully acknowledges financial support from the British Academy (grant COV19\201483).

(c) 2021, Federal Reserve Bank of St. Louis. The views expressed in this article are those of the author(s) and do not necessarily reflect the views of the Federal Reserve System, the Board of Governors, or the regional Federal Reserve Banks. Articles may be reprinted, reproduced, published, distributed, displayed, and transmitted in their entirety if copyright notice, author name(s), and full citation are included. Abstracts, synopses, and other derivative works may be made only with prior written permission of the Federal Reserve Bank of St. Louis. 
Jobs differ by contact intensity and the ease with which they can be performed remotely, in addition to their essential or nonessential classification (Hensvik et al., 2020; Aum et al., 2020b, 2021). Warnings abounded that the economic toll of the pandemic would be unevenly distributed and exacerbate preexisting inequality across demographic and socioeconomic groups, because women and minorities are more likely to work in more-vulnerable jobs (Alon et al., 2020; Blundell et al., 2020). At the onset of the pandemic, near-real-time data revealed that women lost more jobs and were forced to work less, both in the United States and the United Kingdom (Cajner et al., 2020; Adams-Prassl et al., 2020a,b). It also became apparent that minorities were disadvantaged not only because of the types of jobs they held, but also because they were more likely to face employment reductions even within the same jobs as Whites (Montenovo et al., 2020; Cowan, 2020; Gezici and Ozay, 2020).

In this article, we analyze how the initial economic impact of the pandemic and the subsequent recovery differed along numerous dimensions, including gender, race and ethnicity, age, educational attainment, industry, and occupation, and state-level policies and statewide COVID-19 infection rates. The main contribution to the literature is our analysis of the recovery phase through February 2021, as many researchers have documented the early impact of the pandemic in spring $2020 .^{1}$

Our main findings can be summarized as follows:

- Minorities were hit harder by the pandemic, largely due to an industry-occupation composition effect-for example, their disproportionate presence in service industries: the leisure and hospitality industry and the other services industry.

- Many demographic and socioeconomic groups that were hit harder initially have also recovered faster, especially once industry and occupation compositions are taken into account.

- More specifically, the pandemic's differential effects across gender, age, and education vanish by February 2021 once industry and occupation effects are controlled for.

- The differential effects between men and women disappear even when their industry and occupation compositions are not considered, indicating that women's progress in the labor market over the past few decades has not been wiped out by the pandemic.

- Black workers were the least affected by the initial shock among all racial groups, but their recovery has been the slowest, even when industry and occupation effects are controlled for.

- In April 2020, local employment was hit hard in states that had high infection rates, with containment policies having no significant effect on employment. In February 2021, the severity of the epidemic had no systematic effect on employment.

- Urban areas, especially city centers, were hit the hardest and the effects still remain.

We now describe the data and our methodology (Sections 1 and 2) before discussing the results in more detail (Section 3). 


\section{DATA}

We use the monthly Current Population Survey (CPS) from the Bureau of Labor Statistics (BLS). We limit the sample to those 20 to 65 years of age and consider four variables of interest: (i) unemployment, (ii) jobless unemployment, (iii) furlough, or recall, unemployment, and (iv) nonparticipation (not in the labor force). Unemployment and nonparticipation are directly recorded by the BLS. Jobless unemployment and recall unemployment are subcategories of unemployment. The identification of jobless unemployed and recall unemployed relies on the definition in Hall and Kudlyak (2020). The CPS asks respondents if they are currently laid off. If yes, they are asked whether they were given a return date to work or any indication that they would be called back to work within the next six months. If the answer is again yes, they are asked whether they can return if/when recalled. If the answer is also yes, then the respondent is classified as recall unemployed, that is, one who has a job to return to. On the other hand, if a respondent did not work during the survey week, does not expect to be called back, and has been actively looking for work, then they are classified as jobless unemployed. ${ }^{2}$

For demographic and socioeconomic characteristics, we consider gender (male and female), race and ethnicity (White, Black, Hispanic, and Asian), age (20 to 35, 36 to 50, and 51 to 65 years of age), educational attainment (a high school diploma or less education, some college but without a four-year degree, and a bachelor's degree or higher), industry, occupation, and urban/rural residence. We classify industries and occupations into 14 and 11 categories, respectively, based on the major industry recodes and major occupation group recodes provided by the BLS. The CPS has information about whether respondents live in a central city, outside a central city but still in a metropolitan area, or outside a metropolitan area.

We also consider infection rates by state and state government policy responses to the pandemic. Daily case counts from the Centers for Disease Control and Prevention (CDC) COVID Data Tracker are used to calculate the number of cases per 1,000 people. ${ }^{3} \mathrm{We}$ group states into low risk, medium risk, and high risk, with equal numbers of states in each category. In addition, we group states by their policy responses to COVID-19 following the Oxford COVID-19 Government Response Tracker (OxCGRT). ${ }^{4}$ OxCGRT reports 14 time-varying indicators to measure the policy responses of several governments, including those of the 50 U.S. states and Washington, D.C. Each indicator is classified as "containment and closure," "economic response," "health systems," or "miscellaneous" and is used for creating a score for the overall government response (Hale et al., 2020). ${ }^{5}$ Based on these scores, states are grouped into three policy-response categories: (i) robust-response states, which adopted and maintained robust containment, testing, and contact tracing policies; (ii) rapid-rollback states, which adopted a robust response initially but then rolled back policies relatively quickly; and (iii) low-response states, which never adopted particularly restrictive containment measures or robust testing and contact tracing systems. 


\section{ESTIMATION}

The panel dimension of the CPS is short, so it is not possible to track individuals over the course of a year. ${ }^{6}$ We instead estimate the following individual-level linear regression model to capture the factors correlated with the labor market impact of the pandemic:

$$
Y_{i t}^{s}=\alpha+\alpha_{1} \chi_{t=t^{\prime}}+X_{i t}^{s}\left[\beta+\beta_{1} \chi_{t=t^{\prime}}\right]+\epsilon_{i t}^{s} \text {. }
$$

We run the regression separately for $s=4$ (April 2020) and $s=14$ (February 2021), where $t=2019$ or 2020 for $s=4$, and $t=2020$ or 2021 for $s=14$. For each $s, t^{\prime}$ indicates the latter year.

April 2020 was when the pandemic's economic impact was at its peak, and February 2021 was the most recent sample available from the CPS to gauge the recovery process; it is also the last month we can compare annual differences between pre- and post-COVID-19 months. Comparing the same months for 2019 and 2020 or for 2020 and 2021 is informative about the economic effect of the pandemic, seasonally adjusted. The dependent variable $Y_{i t}^{s}$ is a binary variable of individual $i$ 's employment status in month $s$ in year $t$, and we run separate regressions for jobless unemployment, recall unemployment, unemployment, and nonemployment (unemployment plus nonparticipation). ${ }^{7}$

The vector of regressors $X_{i t}^{s}$ includes group dummies on gender, race and ethnicity, education, age, industry, occupation, and geographic location. The location variables include (i) urban/rural residence, (ii) statewide new COVID-19 cases per 1,000 people during the preceding month (to be precise, cumulative counts through April 15, 2020, for the April 2020 regression, and January 15 to February 15, 2021, for the February 2021 regression, since CPS interviews are conducted during the week that contains the 19th of each month), and (iii) the state government's policy response. For April 2020 the state policy responses include only the robust and low-response categories (because no state had a rapid rollback), while for February 2021 they also include the rapid-rollback category.

For each pair of years for the same month, the indicator function $\chi_{t=t^{\prime}}$ equals the latter year (February 2021 or April 2020) and zero otherwise. In this specification, $\beta_{1}$ is the parameter of interest, which captures the differential effects of the pandemic on each demographic and socioeconomic group.

\section{RESULTS}

\subsection{Unemployment by Gender, Race and Ethnicity, Age, and Education}

Before we report the estimation results, we first show the evolution of labor market outcomes as a whole and then by gender, race and ethnicity, age, and educational attainment.

Figure 1 plots the nonparticipation rate, unemployment rate, jobless unemployment rate, and recall unemployment rate from January 2019 onward. The pandemic hit the economy hard in April 2020, when unemployment peaked at 14.8 percent. The economy has since been recovering toward the pre-pandemic levels. Note that the unemployment jump is almost entirely accounted for by recall unemployment, which came down fast in the following months 


\section{Figure 1}

\section{Aggregate Unemployment and Nonemployment Rates}

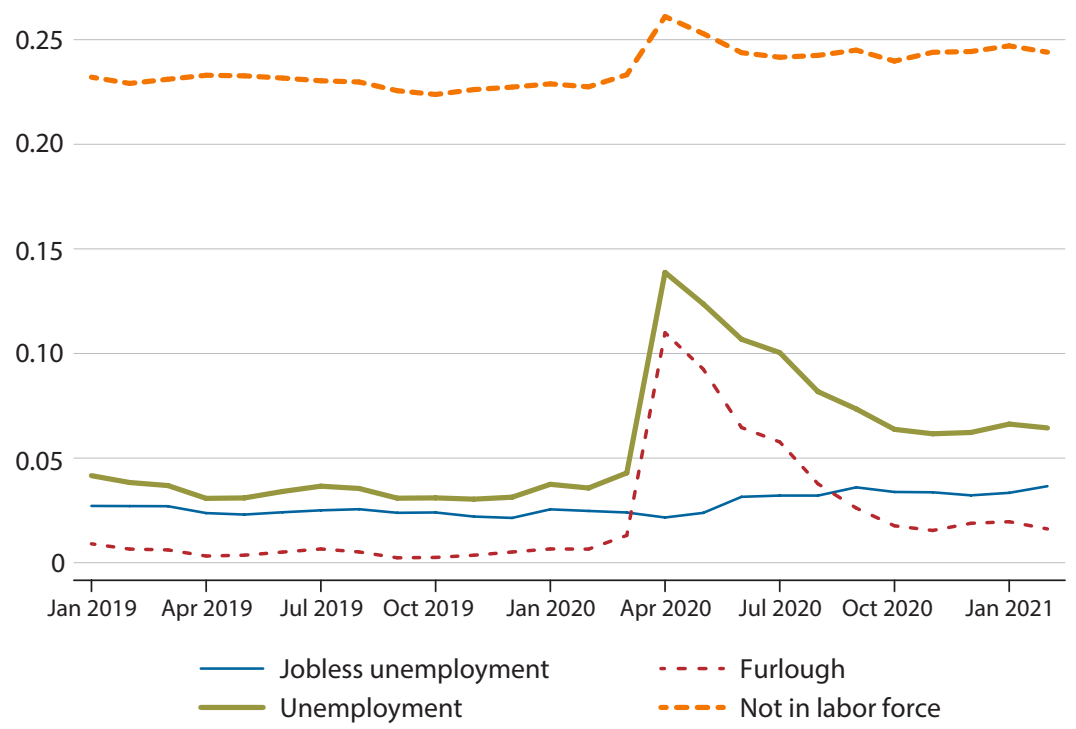

(but was still 1 percentage point higher in February 2021 than in the same month of the previous year). This is broadly consistent with the findings of Hall and Kudlyak (2020). On the other hand, the jobless unemployment rate began to rise in July 2020 and more than twofifths of the year-over-year rise in the unemployment rate as of February 2021 is explained by higher jobless unemployment (1.2 percentage points out of 2.9 percentage points). The pace of recovery has slowed markedly since October 2020. At the time of writing, the unemployment rate in June 2021 was 5.9 percent, down only 1 percentage point from 6.9 percent in October 2020.

Figure 1 also shows that some workers dropped out of the labor force (instead of entering unemployment) when the pandemic hit. The nonparticipation rate increased by 3.1 percentage points between March and April 2020. This is the largest monthly increase ever recorded. For comparison, after the onset of the Great Recession, it took nearly six years for the nonparticipation rate to rise by 3.1 percentage points (from December 2007 to October 2013). The recovery in the nonparticipation rate stalled starting in June 2020 and was still 1.7 percentage points higher in February 2021 than in February 2020.

Figure 2 shows the impact of the pandemic on the employment status of men and women, not controlling for any other variable. In Panel A, for women, the first four bars show the changes in the jobless unemployment, recall unemployment, unemployment, and nonparticipation rates between April 2019 and April 2020, capturing the peak impact of the pandemic. The next four bars show the four rates between February 2020 and February 2021. Panel B is for men. Comparing the two panels, we see that women were hit harder by the pandemic than men: Year-over-year April unemployment rose by 12.7 percentage points for women 


\section{Figure 2}

\section{Labor Market Impact of COVID-19, by Gender}

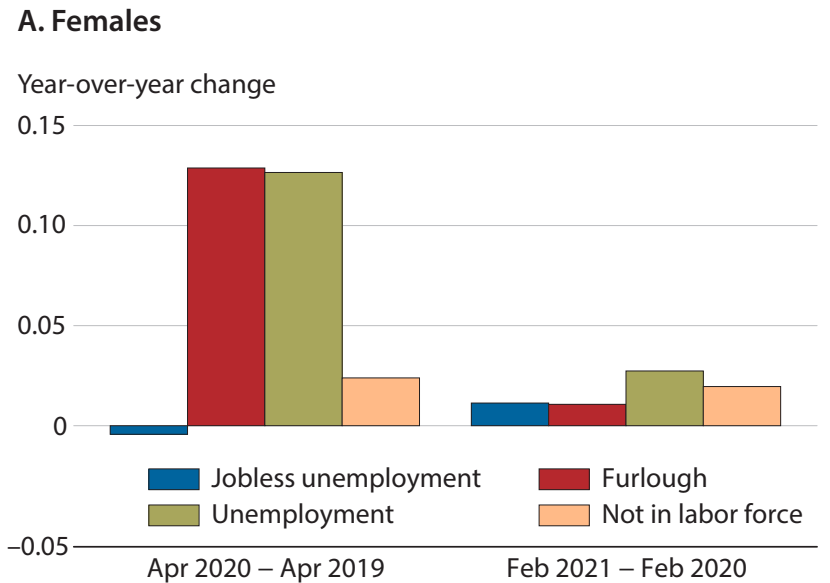

B. Males

Year-over-year change

0.15

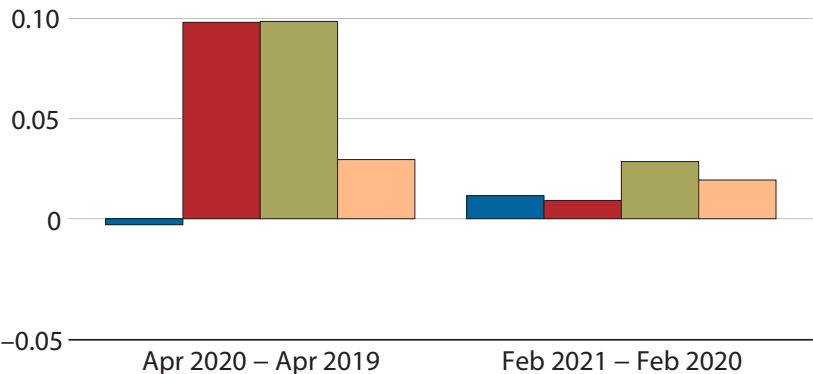

vs. 9.9 percentage points for men, all driven by the rise in recall unemployment. This was a unique phenomenon: Typically men are more adversely affected by recessions than women (Alon et al., 2020). Year-over-year nonparticipation rose slightly more for men than for women (3.0 percentage points vs. 2.4 percentage points). But in February 2021, this gender gap completely disappeared-and even reversed: For men, the unemployment rate rose by 2.9 percentage points relative to February 2020 but for women by 2.7 percentage points. (The year-over-year change in the nonparticipation rate was the same for women and men in February 2021: 1.9 percentage points.) In summary, the pandemic hit women harder initially, but by February 2021 the pandemic's effect on employment was the same for men and women. We again see that the initial impact and the ensuing recovery were driven by recall unemployment.

Figure 3 shows the employment impact across race and ethnicity. Comparing the yearover-year change in the unemployment rate, it is clear that in April 2020 Hispanics were hit harder than any other group (15.1 percentage points), followed by Asians (12.0 percentage points). The unemployment rose the least for Blacks among all groups, including Whites $(10.0$ percentage points vs. 10.2 percentage points), but their nonparticipation rate rose by 5 percentage points, double the increases for Whites and Hispanics. For Whites, the unemployment rate in February 2021 was only 2.1 percentage points higher than in February 2020, a smaller negative effect compared with 4.0 percentage points for Blacks, 4.4 percentage points for Hispanics, and 2.7 percentage points for Asians. It is clear that minorities were hit harder economically by the pandemic and also have been recovering more slowly. The remaining effect on the nonparticipation rate was also larger for minorities, although the magnitude was smaller. The year-over-year changes in the February 2020 nonparticipation rates were 2.2 percentage points, 2.0 percentage points, and 2.0 percentage points for Hispanics, Asians, and Blacks, respectively, compared with 1.8 percentage points for Whites. 


\section{Figure 3}

\section{Labor Market Impact of COVID-19, by Race and Ethnicity}

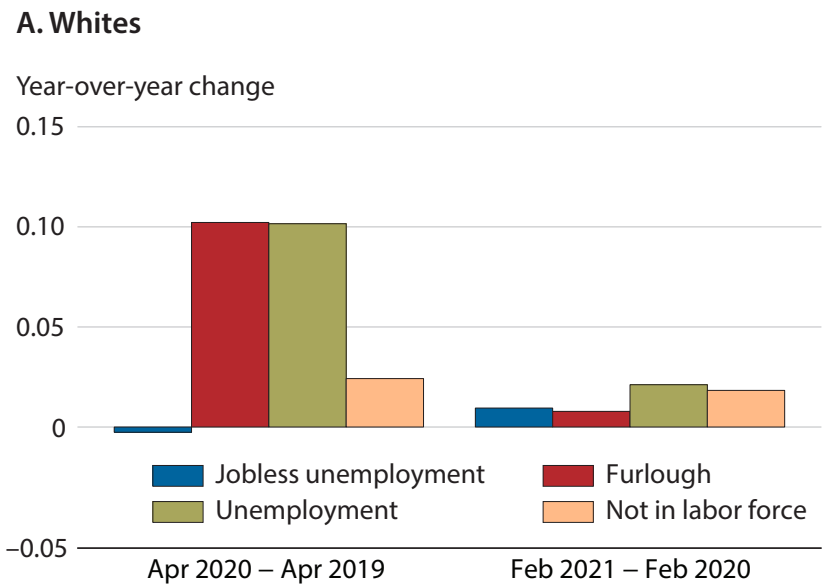

C. Hispanics

Year-over-year change

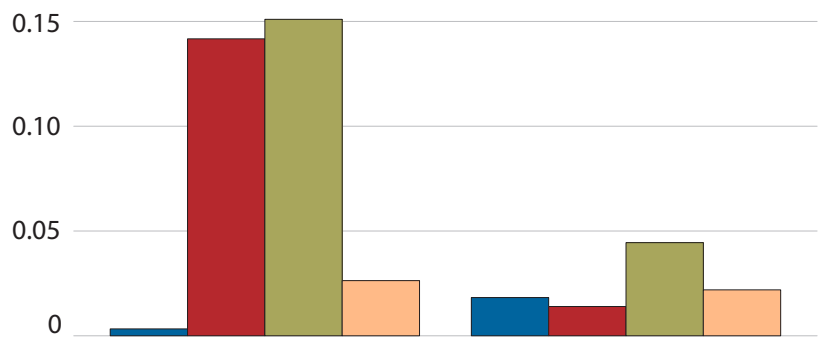

$-0.05$
B. Blacks

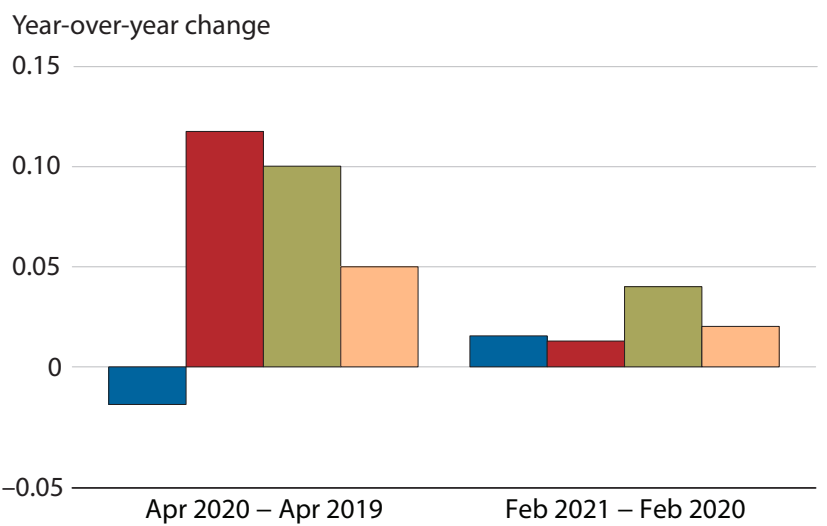

\section{Asians}

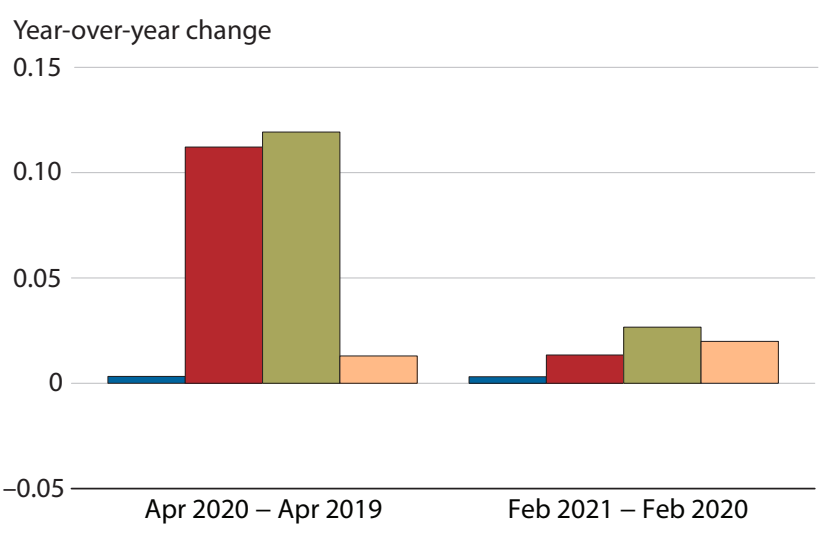

Figure 4 shows how the employment outcomes of different age groups were affected by the COVID-19 shock. Clearly, the young (20 to 35 year olds) were hit the hardest in April 2020: The year-over-year increases in the their unemployment rate and nonparticipation rate were 12.9 percentage points and 4.6 percentage points, respectively. However, in February 2021, the unemployment effects of the pandemic were fairly similar across all three age groups, except the youngest group's nonparticipation rate had not recovered as much, 2.7 percentage points compared with 1.2 percentage points and 0.9 percentage points for the two older groups.

Figure 5 shows the negative employment effects by educational attainment: those with a high school diploma or less education (high school or less), some college but without a fouryear degree (some college), and a bachelor's degree or higher. Consistent with the general findings in the labor literature (e.g., Lee et al., 2015), the patterns for those with high school 
Lee, Park, Shin

\section{Figure 4}

\section{Labor Market Impact of COVID-19, by Age}

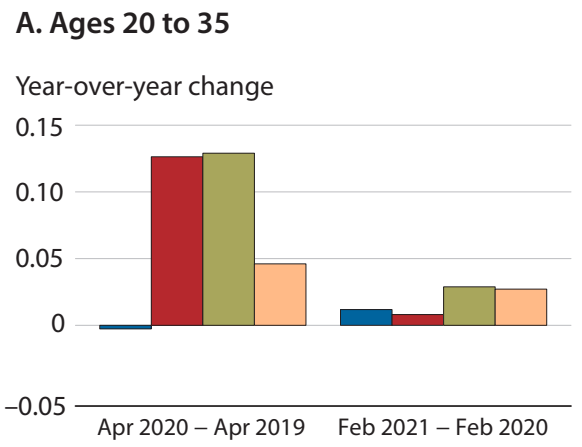

\section{B. Ages 36 to 50}

Year-over-year change

0.15

0.10

0.05

0
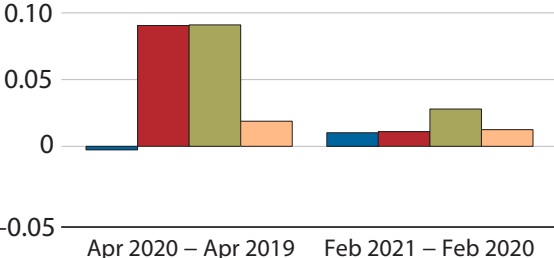

Apr 2020 - Apr 2019 Feb 2021 - Feb 2020

Jobless unemployment

Unemployment

\section{Ages 51 to 65}

Year-over-year change

0.15

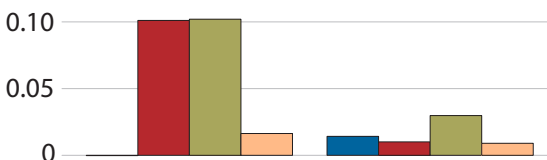

$-0.05-$ Apr 2020 - Apr 2019 Feb $2021-$ Feb 2020

Furlough

Not in labor force

\section{Figure 5}

\section{Labor Market Impact of COVID-19, by Educational Attainment}

\section{A. High school or less}

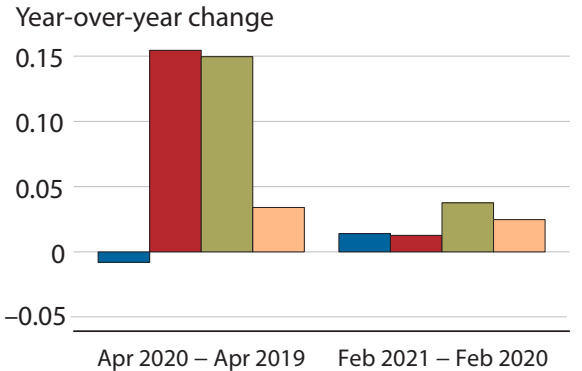

\section{B. Some college}

Year-over-year change

0.15

0.10

0.05

0

$-0.05$

Apr 2020 - Apr 2019 Feb 2021 - Feb 2020

\section{Bachelor's degree or higher}

Year-over-year change

0.15

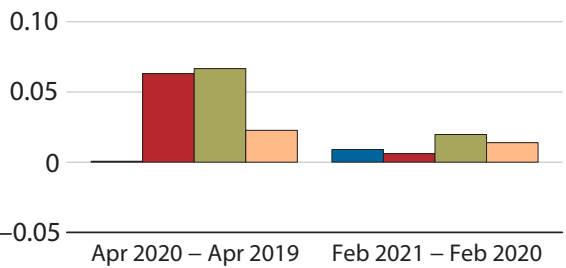

Jobless unemployment

Unemployment

or less and those with some college are broadly similar. The unemployment rate for those with high school or less was higher by 15.0 percentage points in April 2020 than in April 2019 and for those with some college by 13.6 percentage points, while for those with a bachelor's degree or higher it was only 6.7 percentage points higher. (The magnitudes are smaller but the patterns are similar for the nonparticipation rates.) By February 2021, all groups had experienced significant recoveries, again due to the drop in recall unemployment. The unemployment rates were 3.8 percentage points and 3.0 percentage points higher in February 2021 than in February 2020 for those with high school or less and those with some college, respectively, and 2.0 percentage points higher for those with a bachelor's degree or higher. The picture is clear that those with more education were economically less affected by the pandemic. 


\subsection{Estimation Results}

We now turn to the estimates from equation (1). Although the figures in the previous section offer a snapshot of the unequal employment effects of the pandemic across demographic and socioeconomic groups, the effects shown there were confounded by the overlapping compositions across those groups as well as their distributions across industries, occupations, and geographic areas - with all hit differently by the pandemic. Regression (1) can isolate the effect specific to each group, which is captured by the coefficient $\beta_{1}$.

The estimated $\beta_{1}$ for each group (other than the reference group, by construction) is reported in Table 1 for the year-over-year change in April 2020. A significant positive estimate means that the employment outcome of the given group was worse than the reference group's.

Columns 1 to 3 are the estimates for when the outcome variable $Y_{i t}^{s}$ is jobless unemployment, recall unemployment, and unemployment, respectively, and include industry and occupation fixed effects. Since the majority of CPS individuals who do not participate in the labor market do not record their previous industry or occupation, we cannot include such fixed effects for nonemployment (again, unemployment plus nonparticipation) in Column 5. So for ease of interpretation, in Column 4 we also estimate (1) for unemployment without industry and occupation fixed effects. The coefficients on the industry and occupation fixed effects for Columns 1 to 3 are relegated to the tables in the appendix.

This is a saturated regression, and the excluded groups are males, Whites, people with a high school diploma or less education, people between 20 and 35 years of age, and people living in a city center of a state with a robust COVID-19 response and low COVID-19 risk. For regressions with industry and occupation fixed effects, the added excluded groups are the public administration industry and the management, business, and financial occupation category.

The year-over-year increase in the aggregate unemployment rate for April 2020 was 11.1 percentage points. The magnitude of the estimated coefficients in the table can be interpreted relative to this number.

Consistent with the results in Section 3.1, we find that the negative employment effects at the peak of the pandemic were larger for women (than men), for Hispanics and Asians (than Whites or Blacks), for the less educated, and for young workers, controlling for all other factors. These differential effects are smaller with industry and occupation fixed effects (Column 3) than without (Column 4), but they do exist even within occupations and industries. There are two remarkable findings: First, the unemployment effects for Blacks were significantly smaller than those for Whites, with or without industry and occupation fixed effects. Second, despite the larger point estimate for Hispanics, their unemployment rate did not rise significantly more than that for Whites (at the 10 percent significance level) once industry, occupation, and other effects are controlled for, implying that Hispanics were economically exposed to the pandemic by virtue of the types of jobs they held. ${ }^{8}$

Table 1 also shows how state-level policy responses and the extent of the pandemic in the preceding month are correlated with employment outcomes. Somewhat surprisingly, statelevel containment policies had no significant effect on employment. On the other hand, the number of newly confirmed COVID-19 cases leads to (or "Granger causes") more unemploy- 


\section{Table 1}

\section{COVID-19 Shock: April 2020}

\begin{tabular}{|c|c|c|c|c|c|}
\hline & $\begin{array}{c}\text { (1) } \\
\text { Jobless } \\
\text { unemployment }\end{array}$ & $\begin{array}{c}\text { (2) } \\
\text { Furlough }\end{array}$ & $\begin{array}{c}\text { (3) } \\
\text { Unemployment }\end{array}$ & $\begin{array}{c}\text { (4) } \\
\text { Unemployment } \\
\text { without FE }\end{array}$ & $\begin{array}{c}\text { (5) } \\
\text { Nonemployment }\end{array}$ \\
\hline \multicolumn{6}{|c|}{ Gender [Males] } \\
\hline Females $\times 20 / 4$ & $\begin{array}{l}-0.0011 \\
(0.0028)\end{array}$ & $\begin{array}{l}0.0332^{* * *} \\
(0.0042)\end{array}$ & $\begin{array}{l}0.0333^{* * *} \\
(0.0050)\end{array}$ & $\begin{array}{l}0.0353^{* * *} \\
(0.0047)\end{array}$ & $\begin{array}{l}0.0052 \\
(0.0063)\end{array}$ \\
\hline \multicolumn{6}{|c|}{ Race [Whites] } \\
\hline Blacks x 20/4 & $\begin{array}{l}-0.0113^{* *} \\
(0.0052)\end{array}$ & $\begin{array}{l}-0.0127^{*} \\
(0.0067)\end{array}$ & $\begin{array}{l}-0.0230^{* * *} \\
(0.0085)\end{array}$ & $\begin{array}{l}-0.0188^{* *} \\
(0.0087)\end{array}$ & $\begin{array}{l}0.0017 \\
(0.0109)\end{array}$ \\
\hline Hispanics $\times 20 / 4$ & $\begin{array}{l}0.0054 \\
(0.0036)\end{array}$ & $\begin{array}{l}0.0040 \\
(0.0059)\end{array}$ & $\begin{array}{l}0.0127^{*} \\
(0.0070)\end{array}$ & $\begin{array}{l}0.0251^{* * * *} \\
(0.0072)\end{array}$ & $\begin{array}{l}0.0228^{* *} \\
(0.0093)\end{array}$ \\
\hline Asians $\times 20 / 4$ & $\begin{array}{l}0.0030 \\
(0.0045)\end{array}$ & $\begin{array}{l}0.0107 \\
(0.0070)\end{array}$ & $\begin{array}{l}0.0165^{* *} \\
(0.0084)\end{array}$ & $\begin{array}{l}0.0252^{* * *} \\
(0.0087)\end{array}$ & $\begin{array}{l}0.0033 \\
(0.0126)\end{array}$ \\
\hline \multicolumn{6}{|c|}{ Education [High school or less] } \\
\hline Some college $\times 20 / 4$ & $\begin{array}{l}0.0017 \\
(0.0036)\end{array}$ & $\begin{array}{l}0.0062 \\
(0.0059)\end{array}$ & $\begin{array}{l}0.0078 \\
(0.0069)\end{array}$ & $\begin{array}{l}-0.0133^{*} \\
(0.0070)\end{array}$ & $\begin{array}{l}-0.0060 \\
(0.0086)\end{array}$ \\
\hline College $\times 20 / 4$ & $\begin{array}{l}0.0034 \\
(0.0037)\end{array}$ & $\begin{array}{l}-0.0301^{* * * *} \\
(0.0058)\end{array}$ & $\begin{array}{l}-0.0252^{* * *} \\
(0.0070)\end{array}$ & $\begin{array}{l}-0.0856^{* * *} \\
(0.0061)\end{array}$ & $\begin{array}{l}-0.0657^{* * *} \\
(0.0078)\end{array}$ \\
\hline \multicolumn{6}{|c|}{ Age [Ages 20 to 35] } \\
\hline Ages 36 to $50 \times 20 / 4$ & $\begin{array}{l}-0.0013 \\
(0.0031)\end{array}$ & $\begin{array}{l}-0.0160^{* * *} \\
(0.0046)\end{array}$ & $\begin{array}{l}-0.0205^{* * *} \\
(0.0056)\end{array}$ & $\begin{array}{l}-0.0350^{* * *} \\
(0.0058)\end{array}$ & $\begin{array}{l}-0.0465^{* * *} \\
(0.0077)\end{array}$ \\
\hline Ages 51 to $65 \times 20 / 4$ & $\begin{array}{l}0.0011 \\
(0.0031)\end{array}$ & $\begin{array}{l}-0.0083^{*} \\
(0.0048)\end{array}$ & $\begin{array}{l}-0.0117^{* *} \\
(0.0058)\end{array}$ & $\begin{array}{l}-0.0297^{* * *} \\
(0.0060)\end{array}$ & $\begin{array}{l}-0.0556^{* * *} \\
(0.0080)\end{array}$ \\
\hline \multicolumn{6}{|c|}{ Policy [Robust-response states] } \\
\hline Low-response states $\times 20 / 4$ & $\begin{array}{l}-0.0022 \\
(0.0038)\end{array}$ & $\begin{array}{l}-0.0012 \\
(0.0064)\end{array}$ & $\begin{array}{l}-0.0054 \\
(0.0075)\end{array}$ & $\begin{array}{l}-0.0008 \\
(0.0078)\end{array}$ & $\begin{array}{l}-0.0136 \\
(0.0107)\end{array}$ \\
\hline \multicolumn{6}{|c|}{ COVID-19 cases [Low-risk states] } \\
\hline Medium-risk states $\times 20 / 4$ & $\begin{array}{l}0.0010 \\
(0.0032)\end{array}$ & $\begin{array}{l}0.0119 * * \\
(0.0048)\end{array}$ & $\begin{array}{l}0.0119 * * \\
(0.0059)\end{array}$ & $\begin{array}{l}0.0146^{* *} \\
(0.0060)\end{array}$ & $\begin{array}{l}0.0228^{* * * *} \\
(0.0082)\end{array}$ \\
\hline High-risk states $\times 20 / 4$ & $\begin{array}{l}-0.0013 \\
(0.0030)\end{array}$ & $\begin{array}{l}0.0304^{* * *} \\
(0.0046)\end{array}$ & $\begin{array}{l}0.0286^{* * *} \\
(0.0056)\end{array}$ & $\begin{array}{l}0.0317^{* * *} \\
(0.0057)\end{array}$ & $\begin{array}{l}0.0401^{* * *} \\
(0.0077)\end{array}$ \\
\hline \multicolumn{6}{|c|}{ City [Central city] } \\
\hline Outside central city $\times 20 / 4$ & $\begin{array}{l}0.0050^{*} \\
(0.0030)\end{array}$ & $\begin{array}{l}-0.0009 \\
(0.0044)\end{array}$ & $\begin{array}{l}0.0035 \\
(0.0053)\end{array}$ & $\begin{array}{l}-0.0010 \\
(0.0055)\end{array}$ & $\begin{array}{l}0.0000 \\
(0.0073)\end{array}$ \\
\hline Not in metropolitan area $\times 20 / 4$ & $\begin{array}{l}-0.0020 \\
(0.0039)\end{array}$ & $\begin{array}{l}-0.0240^{* * *} \\
(0.0062)\end{array}$ & $\begin{array}{l}-0.0270^{* * *} \\
(0.0074)\end{array}$ & $\begin{array}{l}-0.0320^{* * *} \\
(0.0074)\end{array}$ & $\begin{array}{l}-0.0286^{* * *} \\
(0.0101)\end{array}$ \\
\hline FE & Yes & Yes & Yes & No & No \\
\hline Observations & 78,051 & 78,051 & 78,051 & 78,179 & 103,457 \\
\hline$R^{2}$ & 0.015 & 0.123 & 0.107 & 0.063 & 0.083 \\
\hline \multicolumn{6}{|c|}{$\begin{array}{l}\text { NOTE: FE, industry and occupation fixed effects. Reference groups are in brackets. Robust standard errors are in parentheses. }{ }^{*} p<0.10,{ }^{* *} p<0.05 \text {, } \\
{ }^{* * *} p<0.010 \text {. }\end{array}$} \\
\hline SOURCE: Authors' calculations from $t$ & & & & & \\
\hline
\end{tabular}




\section{Lee, Park, Shin}

ment and nonemployment, suggesting that people's voluntary reduction of economic activities out of fear is an important channel through which the pandemic has hampered the economy. ${ }^{9}$

The final few rows show that those living outside metropolitan areas sustained fewer job losses, even controlling for all other factors. One explanation is that in April 2020, urban areas on average had more stringent lockdowns. (Our policy variables are constructed at the state level.) In addition, with a lower population density in rural areas, even the same social distancing measures represent less of a restriction on economic activities in those areas.

Table 2 shows the estimation results for the changes between February 2020 and February 2021, 10 months into the recovery and the last month we can compare year-over-year with the pre-pandemic statistics. The year-over-year increase in the aggregate unemployment rate was 2.7 percentage points, or only a quarter of the increase in April 2020 over April 2019. This number can help interpret the magnitudes of the estimated coefficients in Table 2.

Consistent with Figure 2, the differential effects of the pandemic on men's and women's unemployment had all but disappeared by February 2021. Controlling for industries and occupations, the differential effects on women's furloughs and unemployment are statistically significant but the magnitudes are small.

As for minorities, only Blacks exhibit a larger shock to unemployment when industry and occupation fixed effects are controlled for (Column 3). Since Blacks were hit less hard than even Whites in April 2020, this finding shows that Blacks have been the slowest to recover. Hispanics still have a somewhat higher unemployment effect in Column 4, implying that they tend to work for industries and in occupations that have been recovering more slowly. However, in terms of nonemployment, there is no difference across these groups even when industry and occupation compositions are not considered.

We also see that by February 2021, differential effects across education groups and across age groups evaporate once industries and occupations are controlled for. ${ }^{10}$ The larger effects on the nonemployment of the young and the less educated (column 5) show that these are compositional effects: The industries and occupations that are over-represented by these groups have been recovering more slowly than other industries and occupations. ${ }^{11}$

Table 2 also shows that state-level policies do have some effect on employment outcomes in February 2021, but the differences are negligible once industries and occupations are controlled for. At the same time, somewhat surprisingly, medium-risk states had better outcomes and high-risk states had only slightly worse outcomes than low-risk states. This suggests that the fear effect evident in April 2020 may have lessened thereafter, possibly because people reassessed infection risks or adopted other ways of mitigating the risk (e.g., wearing masks). ${ }^{12}$

Finally, the employment of city center residents has been the slowest to recover. The most likely explanation is that remote work reduced not only the number of workers in city centers but also these workers' demand for local consumer service businesses, further worsening the employment prospects of city center residents (Eckert et al., 2020).

\section{CONCLUDING REMARKS}

The economic impact of the pandemic was unequal across demographic and socioeconomic groups. The initial shock hit women harder than men, but the differential effects 
disappeared by February 2021. Similarly, Hispanics and Asians were hit harder than Blacks and Whites in April 2020, but both groups have recovered quite a bit, especially Hispanics. Blacks on the other hand, in spite of having a smaller initial shock than all other racial groups, have experienced slower recoveries in their employment outcomes. These results remain even after controlling for all other factors, including industries, occupations, state-level policies and statewide infection rates, and urban/rural residence. In this context, it is not clear what explains the slower reduction of Black unemployment. One possibility is that our industry and occupation classifications are not detailed enough (a choice we made in recognition of the sample size of the CPS) and we are not fully capturing the compositional effects. We leave this question for future research but note that the remaining effect on the Black nonemployment rate is not significantly different from that for Whites in February 2021.

By educational attainment, the less educated were hit worse than the more educated in April 2020. By February 2021, the differential effects across education groups had gotten smaller but still remained due to the different industries and occupations they work in.

In addition, while the young were harder hit initially, by February 2021, there was no systematic difference in the employment impact of the pandemic across age groups, except that the young in certain industries and occupations had left the workforce altogether.

Our findings call for a careful investigation of the mechanism through which different demographic and socioeconomic groups have been affected unequally by the pandemic, not only on impact but also during the recovery.

\section{APPENDIX}

Tables A1 and A2 report the coefficients on the industry and occupation fixed effects in regressions (1) to (3) of Tables 1 and 2 in the main text.

By industry, we see that the leisure and hospitality industry and the other services industry were hit the hardest, and they still had not recovered even by February 2021. However, taking into account the large, negative initial hit the other services industry took, it showed the fastest recovery. On the other hand, the public administration industry and the agriculture industry not only suffered less but also recovered faster than most other industries. Since most agricultural work can be done outdoors with ample room for social distancing, this finding is not surprising. Although the initial impact of the shock was hard on the manufacturing industry and the education and health services industry, their speeds of recovery surpassed even that of the public administration industry. The financial activities industry was relatively safe, which contrasts with the effect on that industry from the 2008-09 Financial Crisis.

Looking into occupations, we find that service and construction occupations were the hardest hit and slowest to recover. Production occupations also suffered initially but recovered faster than other occupations. Management, business, and financial occupations; office and administrative support occupations; and professional and related occupations suffered the least and also recovered the fastest. This may have been thanks to their ability to work remotely, which is in line with results from Montenovo et al. (2020). 
Table A1

COVID-19 Shock: April 2020

(1)

Jobless

unemployment
(2)

Furlough

Unemployment

\begin{tabular}{|c|c|c|c|}
\hline \multicolumn{4}{|c|}{ Industry [Public administration] } \\
\hline Mining $\times 20 / 4$ & $\begin{array}{l}0.0268 \\
(0.0174)\end{array}$ & $\begin{array}{l}0.0170 \\
(0.0163)\end{array}$ & $\begin{array}{l}0.0559 * * \\
(0.0258)\end{array}$ \\
\hline Construction x 20/4 & $\begin{array}{l}-0.0138^{*} \\
(0.0074)\end{array}$ & $\begin{array}{l}0.0731^{* * *} \\
(0.0108)\end{array}$ & $\begin{array}{l}0.0609 * * * \\
(0.0134)\end{array}$ \\
\hline Manufacturing $\times 20 / 4$ & $\begin{array}{l}0.0041 \\
(0.0053)\end{array}$ & $\begin{array}{l}0.0660^{* * *} \\
(0.0081)\end{array}$ & $\begin{array}{l}0.0728^{* * *} \\
(0.0102)\end{array}$ \\
\hline Wholesale and retail trade $\times 20 / 4$ & $\begin{array}{l}-0.0007 \\
(0.0060)\end{array}$ & $\begin{array}{l}0.0747^{* * *} \\
(0.0086)\end{array}$ & $\begin{array}{l}0.0756^{* * *} \\
(0.0109)\end{array}$ \\
\hline Transportation and utilities $\times 20 / 4$ & $\begin{array}{l}-0.0076 \\
(0.0067)\end{array}$ & $\begin{array}{l}0.0619 * * * \\
(0.0100)\end{array}$ & $\begin{array}{l}0.0539 * * * \\
(0.0124)\end{array}$ \\
\hline Information $\times 20 / 4$ & $\begin{array}{l}0.0145 \\
(0.0104)\end{array}$ & $\begin{array}{l}0.0494^{* * *} \\
(0.0119)\end{array}$ & $\begin{array}{l}0.0706^{* * * *} \\
(0.0171)\end{array}$ \\
\hline Financial activities $\times 20 / 4$ & $\begin{array}{l}0.0004 \\
(0.0055)\end{array}$ & $\begin{array}{l}0.0186^{* * *} \\
(0.0070)\end{array}$ & $\begin{array}{l}0.0220^{* *} \\
(0.0094)\end{array}$ \\
\hline Professional and business services $\times 20 / 4$ & $\begin{array}{l}0.0041 \\
(0.0048)\end{array}$ & $\begin{array}{l}0.0384^{* * *} \\
(0.0068)\end{array}$ & $\begin{array}{l}0.0444^{* * *} \\
(0.0087)\end{array}$ \\
\hline Education and health services $\times 20 / 4$ & $\begin{array}{l}0.0048 \\
(0.0040)\end{array}$ & $\begin{array}{l}0.0620^{* * *} \\
(0.0065)\end{array}$ & $\begin{array}{l}0.0678^{* * * *} \\
(0.0079)\end{array}$ \\
\hline Leisure and hospitality $\times 20 / 4$ & $\begin{array}{l}0.0146^{* *} \\
(0.0071)\end{array}$ & $\begin{array}{l}0.2450^{* * *} \\
(0.0120)\end{array}$ & $\begin{array}{l}0.2740^{* * *} \\
(0.0136)\end{array}$ \\
\hline Other services $\times 20 / 4$ & $\begin{array}{l}0.0074 \\
(0.0061)\end{array}$ & $\begin{array}{l}0.1340^{* * *} \\
(0.0125)\end{array}$ & $\begin{array}{l}0.1500^{* * * *} \\
(0.0142)\end{array}$ \\
\hline Agriculture, forestry, fishing, and hunting $\times 20 / 4$ & $\begin{array}{l}0.0025 \\
(0.0134)\end{array}$ & $\begin{array}{l}0.0153 \\
(0.0132)\end{array}$ & $\begin{array}{l}0.0206 \\
(0.0186)\end{array}$ \\
\hline \multicolumn{4}{|c|}{ Occupation [Management, business, and financial] } \\
\hline Professional and related $\times 20 / 4$ & $\begin{array}{l}-0.0062^{*} \\
(0.0034)\end{array}$ & $\begin{array}{l}0.0332^{* * *} \\
(0.0045)\end{array}$ & $\begin{array}{l}0.0260^{* * * *} \\
(0.0059)\end{array}$ \\
\hline Service $\times 20 / 4$ & $\begin{array}{l}-0.0072 \\
(0.0048)\end{array}$ & $\begin{array}{l}0.1150^{* * *} \\
(0.0079)\end{array}$ & $\begin{array}{l}0.1120^{* * * *} \\
(0.0093)\end{array}$ \\
\hline Sales and related $\times 20 / 4$ & $\begin{array}{l}-0.0114^{*} \\
(0.0059)\end{array}$ & $\begin{array}{l}0.0668^{* * *} \\
(0.0079)\end{array}$ & $\begin{array}{l}0.0643^{* * * *} \\
(0.0101)\end{array}$ \\
\hline Office and administrative support $\times 20 / 4$ & $\begin{array}{l}-0.0105^{* *} \\
(0.0048)\end{array}$ & $\begin{array}{l}0.0395^{* * *} \\
(0.0064)\end{array}$ & $\begin{array}{l}0.0330^{* * * *} \\
(0.0082)\end{array}$ \\
\hline Farming, fishing, and forestry $\times 20 / 4$ & $\begin{array}{l}-0.0492^{* *} \\
(0.0223)\end{array}$ & $\begin{array}{l}0.0622^{* *} \\
(0.0256)\end{array}$ & $\begin{array}{l}0.0096 \\
(0.0330)\end{array}$ \\
\hline Construction and extraction $\times 20 / 4$ & $\begin{array}{l}0.0147^{*} \\
(0.0086)\end{array}$ & $\begin{array}{l}0.0881^{* * *} \\
(0.0122)\end{array}$ & $\begin{array}{l}0.1110^{* * *} \\
(0.0152)\end{array}$ \\
\hline Installation, maintenance, and repair $\times 20 / 4$ & $\begin{array}{l}-0.0132^{*} \\
(0.0071)\end{array}$ & $\begin{array}{l}0.0573^{* * *} \\
(0.0123)\end{array}$ & $\begin{array}{l}0.0462^{* * *} \\
(0.0146)\end{array}$ \\
\hline Production $\times 20 / 4$ & $\begin{array}{l}-0.0163^{* *} \\
(0.0069)\end{array}$ & $\begin{array}{l}0.1020^{* * *} \\
(0.0112)\end{array}$ & $\begin{array}{l}0.0922^{* * * *} \\
(0.0134)\end{array}$ \\
\hline Transportation and material moving $\times 20 / 4$ & $\begin{array}{l}-0.0014 \\
(0.0073)\end{array}$ & $\begin{array}{l}0.0738^{* * *} \\
(0.0100)\end{array}$ & $\begin{array}{l}0.0784^{* * *} \\
(0.0125)\end{array}$ \\
\hline Observations & 78,051 & 78,051 & 78,051 \\
\hline$R^{2}$ & 0.015 & 0.123 & 0.107 \\
\hline $\begin{array}{l}\text { NOTE: Reference groups are in brackets. Robust stand } \\
\text { SOURCE: Authors' calculations from the CPS. }\end{array}$ & ors are in pare & ${ }^{*} p<0.10,{ }^{* *} p$ & ${ }^{* *} p<0.010$. \\
\hline
\end{tabular}


Table A2

COVID-19 Recovery: February 2021

(1)

Jobless

unemployment
(2)

(3)

\begin{tabular}{|c|c|c|c|}
\hline & $\begin{array}{c}\text { Jobless } \\
\text { unemployment }\end{array}$ & Furlough & Unemployment \\
\hline \multicolumn{4}{|c|}{ Industry [Public administration] } \\
\hline Mining $\times 21 / 2$ & $\begin{array}{l}0.0360 \\
(0.0310)\end{array}$ & $\begin{array}{l}0.0208 \\
(0.0155)\end{array}$ & $\begin{array}{l}0.1070 * * \\
(0.0415)\end{array}$ \\
\hline Construction $\times 21 / 2$ & $\begin{array}{l}0.0069 \\
(0.0074)\end{array}$ & $\begin{array}{l}0.0064 \\
(0.0055)\end{array}$ & $\begin{array}{l}0.0257^{* *} \\
(0.0103)\end{array}$ \\
\hline Manufacturing $\times 21 / 2$ & $\begin{array}{l}-0.0009 \\
(0.0060)\end{array}$ & $\begin{array}{l}-0.0019 \\
(0.0037)\end{array}$ & $\begin{array}{l}0.0022 \\
(0.0079)\end{array}$ \\
\hline Wholesale and retail trade $\times 21 / 2$ & $\begin{array}{l}0.0155^{* *} \\
(0.0068)\end{array}$ & $\begin{array}{l}-0.0002 \\
(0.0037)\end{array}$ & $\begin{array}{l}0.0245^{* * *} \\
(0.0085)\end{array}$ \\
\hline Transportation and utilities $\times 21 / 2$ & $\begin{array}{l}0.0135^{*} \\
(0.0080)\end{array}$ & $\begin{array}{l}0.0061 \\
(0.0050)\end{array}$ & $\begin{array}{l}0.0315^{* * *} \\
(0.0104)\end{array}$ \\
\hline Information $\times 21 / 2$ & $\begin{array}{l}0.0276^{* *} \\
(0.0111)\end{array}$ & $\begin{array}{l}0.0046 \\
(0.0049)\end{array}$ & $\begin{array}{l}0.0365^{* * *} \\
(0.0135)\end{array}$ \\
\hline Financial activities $\times 21 / 2$ & $\begin{array}{l}0.0103^{*} \\
(0.0063)\end{array}$ & $\begin{array}{l}-0.0002 \\
(0.0033)\end{array}$ & $\begin{array}{l}0.0127 \\
(0.0079)\end{array}$ \\
\hline Professional and business services $\times 21 / 2$ & $\begin{array}{l}0.0086 \\
(0.0059)\end{array}$ & $\begin{array}{l}0.0018 \\
(0.0038)\end{array}$ & $\begin{array}{l}0.0144^{*} \\
(0.0076)\end{array}$ \\
\hline Education and health services $\times 21 / 2$ & $\begin{array}{l}-0.0022 \\
(0.0046)\end{array}$ & $\begin{array}{l}-0.0013 \\
(0.0029)\end{array}$ & $\begin{array}{l}-0.0024 \\
(0.0061)\end{array}$ \\
\hline Leisure and hospitality $\times 21 / 2$ & $\begin{array}{l}0.0294^{* * *} \\
(0.0085)\end{array}$ & $\begin{array}{l}0.0132^{* * *} \\
(0.0050)\end{array}$ & $\begin{array}{l}0.0610^{* * *} \\
(0.0107)\end{array}$ \\
\hline Other services $\times 21 / 2$ & $\begin{array}{l}0.0159^{* *} \\
(0.0077)\end{array}$ & $\begin{array}{l}0.0067 \\
(0.0046)\end{array}$ & $\begin{array}{l}0.0326 * * * \\
(0.0102)\end{array}$ \\
\hline Agriculture, forestry, fishing, and hunting $\times 21 / 2$ & $\begin{array}{l}-0.0201^{*} \\
(0.0116)\end{array}$ & $\begin{array}{l}0.0281^{*} \\
(0.0159)\end{array}$ & $\begin{array}{l}0.0165 \\
(0.0203)\end{array}$ \\
\hline \multicolumn{4}{|c|}{ Occupation [Management, business, and financial] } \\
\hline Professional and related $\times 21 / 2$ & $\begin{array}{l}0.0009 \\
(0.0038)\end{array}$ & $\begin{array}{l}-0.0003 \\
(0.0018)\end{array}$ & $\begin{array}{l}0.0008 \\
(0.0046)\end{array}$ \\
\hline Service $\times 21 / 2$ & $\begin{array}{l}0.0181^{* * *} \\
(0.0058)\end{array}$ & $\begin{array}{l}0.0069 * * \\
(0.0034)\end{array}$ & $\begin{array}{l}0.0386^{* * *} \\
(0.0073)\end{array}$ \\
\hline Sales and related $\times 21 / 2$ & $\begin{array}{l}-0.0056 \\
(0.0066)\end{array}$ & $\begin{array}{l}0.0059 * \\
(0.0033)\end{array}$ & $\begin{array}{l}0.0023 \\
(0.0079)\end{array}$ \\
\hline Office and administrative support $\times 21 / 2$ & $\begin{array}{l}0.0044 \\
(0.0053)\end{array}$ & $\begin{array}{l}-0.0003 \\
(0.0026)\end{array}$ & $\begin{array}{l}0.0115^{*} \\
(0.0066)\end{array}$ \\
\hline Farming, fishing, and forestry $\times 21 / 2$ & $\begin{array}{l}0.0350 \\
(0.0257)\end{array}$ & $\begin{array}{l}-0.0349 \\
(0.0243)\end{array}$ & $\begin{array}{l}0.0004 \\
(0.0363)\end{array}$ \\
\hline Construction and extraction $\times 21 / 2$ & $\begin{array}{l}0.0156^{*} \\
(0.0091)\end{array}$ & $\begin{array}{l}0.0096 \\
(0.0073)\end{array}$ & $\begin{array}{l}0.0266^{* *} \\
(0.0128)\end{array}$ \\
\hline Installation, maintenance, and repair $\times 21 / 2$ & $\begin{array}{l}0.0022 \\
(0.0074)\end{array}$ & $\begin{array}{l}0.0016 \\
(0.0044)\end{array}$ & $\begin{array}{l}0.0134 \\
(0.0102)\end{array}$ \\
\hline Production $\times 21 / 2$ & $\begin{array}{l}0.0021 \\
(0.0086)\end{array}$ & $\begin{array}{l}0.0018 \\
(0.0051)\end{array}$ & $\begin{array}{l}0.0109 \\
(0.0108)\end{array}$ \\
\hline Transportation and material moving $\times 21 / 2$ & $\begin{array}{l}0.0135^{*} \\
(0.0079)\end{array}$ & $\begin{array}{l}0.0114^{* *} \\
(0.0049)\end{array}$ & $\begin{array}{l}0.0267^{* * *} \\
(0.0100)\end{array}$ \\
\hline Observations & 73,926 & 73,926 & 73,926 \\
\hline$R^{2}$ & 0.021 & 0.017 & 0.036 \\
\hline \multicolumn{4}{|c|}{$\begin{array}{l}\text { NOTE: Reference groups are in brackets. Robust standard errors are in parentheses. }{ }^{*} p<0.10,{ }^{* *} p<0.05,{ }^{* *} p<0.010 \text {. } \\
\text { SOURCE: Authors' calculations from the CPS. }\end{array}$} \\
\hline
\end{tabular}




\section{Lee, Park, Shin}

\section{NOTES}

1 The paper most closely related to ours is Couch, Fairlie, and Xu (2020), which compares the experiences of Blacks, Hispanics, and Asians relative to those of Whites from April to June 2020. Our results complement theirs with data from later months and show new evidence for the recovery phase.

2 When added together, the total for recall unemployment and jobless unemployment is smaller than total unemployment, but the difference is small.

3 The CDC COVID Data Tracker is available at https://covid.cdc.gov/covid-data-tracker.

4 The OxCGRT is available at www.bsg.ox.ac.uk/research/research-projects/coronavirus-government-response-tracker.

5 The online repository provides detailed coding information and is available at https://github.com/OxCGRT/ covid-policy-tracker/blob/master/documentation/codebook.md.

6 The CPS has outgoing rotation samples, and the BLS interviews each household for four consecutive months. The household leaves the sample for the next eight months and returns for another four months. The sample-collecting process happens every month, so only a quarter of the sample can be tracked from one month to the next.

7 We have analyzed all months from October 2020 to February 2021. From November 2020 onward, there are almost no differences in our estimates. Lee, Park, and Shin (2021), the earlier version of this article, has the results through November 2020.

8 Table A1 in the appendix, for April 2020, shows that by industry, the leisure and hospitality industry and the other services industry were hit the hardest, while the service, construction, and production occupations suffered more than other occupations.

9 This is consistent with evidence from other countries. See Aum et al. (2020a), for example.

10 The results show that by February 2021 the impact on more-educated and less-educated workers was consistent with that in Forsythe et al. (2021), which shows that labor market tightness converged for college-educated and high-school workers.

${ }^{11}$ Among industries, as of February 2021, the leisure and hospitality industry had not recovered from the shock. There is not much of a pattern across occupations, except that service occupations still showed a significantly higher unemployment rate from their February 2020 level.

12 These estimates are different from the November 2020 estimates. In the November data, states that rolled back containment policies or implemented less-restrictive policies had a smaller year-over-year rise in unemployment than states with more-restrictive policies. Furthermore, statewide infection rates in the preceding month were uncorrelated with employment outcomes.

\section{REFERENCES}

Adams-Prassl, A.; Boneva, T.; Golin, M. and Rauh, C. "Furloughing." Fiscal Studies, 2020a, 41(3), pp. 591-622; https://doi.org/10.1111/1475-5890.12242.

Adams-Prassl, A.; Boneva, T.; Golin, M. and Rauh, C. "Inequality in the Impact of the Coronavirus Shock: Evidence from Real Time Surveys." Journal of Public Economics, 2020b, 189, https://doi.org/10.1016/j.jpubeco.2020.104245.

Alon, T.; Doepke, M.; Olmstead-Rumsey, J. and Tertilt, M. "The Impact of COVID-19 on Gender Equality." NBER Working Paper 26947, National Bureau of Economic Research, April 2020; https://www.nber.org/system/files/working papers/w26947/w26947.pdf.

Aum, S.; Lee, S.Y.T. and Shin, Y. “COVID-19 Doesn't Need Lockdowns to Destroy Jobs: The Effect of Local Outbreaks in Korea." NBER Working Paper 27264, National Bureau of Economic Research, May 2020a; https://doi.org/10.3386/w27264.

Aum, S.; Lee, S.Y.T. and Shin, Y. "Who Should Work from Home During a Pandemic? The Wage-Infection Trade-off." NBER Working Paper 27908, National Bureau of Economic Research, October 2020b; https://doi.org/10.3386/w27908. 
Aum, S.; Lee, S.Y.T. and Shin, Y. "Inequality of Fear and Self-quarantine: Is There a Trade-Off Between GDP and Public Health?" Journal of Public Economics, February 2021, 194, https://doi.org/10.1016/j.jpubeco.2020.104354.

Blundell, R.; Costa Dias, M.; Joyce, R. and Xu, X. "COVID-19 and Inequalities." Fiscal Studies, 2020, 41(2), pp. 291-319; https://doi.org/10.1111/1475-5890.12232.

Cajner, T.; Crane, L.D.; Decker, R.A.; Grigsby, J.; Hamins-Puertolas, A.; Hurst, E.; Kurz, C. and Yildirmaz, A. "The U.S. Labor Market during the Beginning of the Pandemic Recession." NBER Working Paper 27159, National Bureau of Economic Research, May 2020; https://www.nber.org/papers/w27159.

Couch, K.A.; Fairlie, R.W. and Xu, H. "Early Evidence of the Impacts of COVID-19 on Minority Unemployment." Journal of Public Economics, 2020, 192; https://doi.org/10.1016/j.jpubeco.2020.104287.

Cowan, B.W. "Short-Run Effects of COVID-19 on U.S. Worker Transitions." NBER Working Paper 27315, National Bureau of Economic Research, June 2020; https://doi.org/10.3386/w27315.

Eckert, F.; Ganapati, S. and Walsh, C. "The City Paradox: Skilled Services and Remote Work." Opportunity and Inclusive Growth Institute Working Paper 43, Federal Reserve Bank of Minneapolis, December 2020; https://www.minneapolisfed.org/research/institute-working-papers/the-city-paradox-skilled-services-and-remote-work.

Forsythe, E., Kahn, L.B.; Lange, F. and Wiczer, D. "Searching, Recalls, and Tightness: An Interim Report on the Covid Labor Market." Unpublished manuscript, 2021.

Gezici, A. and Ozay, O. "How Race and Gender Shape COVID-19 Unemployment Probability." PERI Working Paper 521, University of Massachusetts Amherst, August 2020.

Hale, T.; Atav, T.; Hallas, L.; Kira, B.; Phillips, T.; Petherick, A. and Pott, A. "Variation in US States' Responses to COVID-19." BSG Working Paper Series 2020/034, Blavatnik School of Government, University of Oxford, December 2020.

Hall, R.E. and Kudlyak, M. “Unemployed with Jobs and without Jobs.” NBER Working Paper 27886, National Bureau of Economic Research, October 2020; https://www.nber.org/system/files/working papers/w27886/w27886.pdf.

Hensvik, L.; Barbanchon, T.L. and Rathelot, R. “Which Jobs Are Done from Home? Evidence from the American Time Use Survey." CEPR Discussion Paper 14611, Centre for Economic Policy Research, 2020; https://cepr.org/active/publications/discussion_papers/dp.php?dpno=14611.

Lee, S.Y.T.; Park, M. and Shin, Y. "Hit Harder, Recover Slower? Unequal Employment Effects of the COVID-19 Shock." NBER Working Papers 28354, National Bureau of Economic Research, January 2021; https://www.nber.org/system/files/working_papers/w28354/w28354.pdf.

Lee, S.Y.T.; Shin, Y. and Lee, D. "The Option Value of Human Capital: Higher Education and Wage Inequality." NBER Working Paper 21724, National Bureau of Economic Research, November 2015; https://www.nber.org/papers/w21724.

Montenovo, L.; Jiang, X.; Rojas, F.L.; Schmutte, I.M.; Simon, K.I.; Weinberg, B.A. and Wing, C. “Determinants of Disparities in COVID-19 Job Losses." NBER Working Paper 27132, National Bureau of Economic Research, May 2020; https://www.nber.org/papers/w27132. 